\title{
WHAT MAY BE ACCOMPLISHED BY RECLAMATION
}

\author{
By Hon. Frederick H. Newell,
}

Director United States Reclamation Service, Washington, D. C.

In the conservation of natural resources reclamation plays a very large part, both directly and indirectly. There is involved in the idea of reclamation not merely the better use of lands otherwise practically valueless, but in connection with this the creation of opportunities for homes; also, but secondary to this, is frequently brought in the storage or disposal of waters in such way as to render possible the use of these waters for power or other industrial purposes, including the manufacture of electricity for lighting, heating and transportation.

The word "reclamation" as now commonly employed involves the conception of regulating the water supply for a given area of land, which, under natural conditions, has an excess or deficiency of moisture so great that agricultural values are nearly or completely destroyed. We speak of reclaiming the swamp or overflowed lands by keeping the waters off them, or of reclaiming arid lands by bringing waters to them at the time and in the quantities best adapted for the development of plants useful to mankind.

The National Government has been and still is an owner of vast areas of reclaimable land. In the early history of the life of the nation, individuals initiated works for draining and reclaiming areas of low-lying but very fertile land. Later, to promote the reclamation of these, Congress passed laws which, in general terms, conveyed to the separate states the title of the swamp and overflowed lands within their borders in order that these lands might be reclaimed by the state through corporate as well as individual activities. The grants were not, however, sufficiently well guarded to secure the desired results, and although practically all of the states eagerly sought and acquired the swamp lands and passed them over to individuals and corporations, very little was ever done to reclaim and utilize these lands. They became objects of speculation, and vast areas still remain in the hands of men who are holding them for rise in prices. The experience of this kind of legislation had 
strong influence on subsequent debates in Congress on measures to promote the reclamation of arid lands. The failure of the states to secure reclamation of the swamp lands was a very powerful argument against giving the arid lands to the states in which they were situated, although very convincing pleas were advanced why this work should be confided to the state officials.

There remains yet to be worked out some feasible scheme by which the vast areas of swamp and overflowed lands whose title is now in private ownership may be reclaimed, subdivided, and put in the hands of men who will cultivate them. The soil of these swamp lands is extremely fertile and with effective systems of drainage the lands are capable not merely of supporting large and prosperous agricultural communities, but will be sources of strength to each commonwealth in which they are situated, instead of being, as now, breeding places of mosquitoes and other pests, centers of disease and a menace to land values in the neighborhood.

It may be possible after diffusing information and stimulating public interest to bring together the diverse interests and ultimately to reclaim the large tracts of the swamp land donated to the states, but this can come about on a broad scale only after careful study of the entire situation and the adoption of far-reaching plans. It is, of course, possible to take up one particular tract and build levees, dikes and drains, but it frequently happens that the plans made for one area are such as seriously to interfere with the development of another or more important piece of land; or the system proposed for several areas may be such as not to provide adequate waterways for tracts higher up, and thus disaster may follow the carrying out of schemes which are not sufficiently broad to take in all the surrounding conditions. Where, on the contrary, plans for reclamation start with a full knowledge of all the conditions as they exist and a comprehension of ideal results to be attained, it should result that with the execution of these plans, great tracts of fertile but water-clogged soil will be made available for agriculture.

The term "reclamation" has of late been popularly used with a somewhat restricted meaning, as applying to the irrigation of arid lands and the bringing on of a needed amount of water at proper seasons. Reclamation in this sense has been undertaken by the National Government under the terms of an act passed June r7, I902, which creates a special fund in the treasury out of the pro- 
ceeds of the disposal of public lands. This fund is entirely distinct from the general revenues of the Government, derived by imposts or taxation, and hence it is not subject to many of the constitutional limitations which are imposed upon acts of Congress. The expenditure of the reclamation fund has been placed by Congress in the hands of the Secretary of the Interior for the purpose of making surveys and examinations and later constructing feasible projects for the reclamation by irrigation of arid and semi-arid lands. $\mathrm{He}$ is also charged with the duty of maintaining and operating these projects until the charges for water for the major portions of the land have been repaid, when the burden of operation and maintenance passes to the owners of the lands.

The Reclamation Act is very general in character and imposes large discretion upon the secretary. In order to carry it out, he has organized what is known as the Reclamation Service, which is practically a bureau of the Department of the Interior. This service consists of men selected through competitive civil service examinations, based largely on practical experience, and who have made a record for efficiency each in his specialty. This organization has been in existence for a little over six years, and during that time, under the direction of the Secretary of the Interior, has made plans for many important works, and has erected a number of these, the estimated expenditures being in round numbers fifty millions of dollars. Already nearly a million acres have been placed under irrigation, and a third of this has been actually watered. Large dams and other structures for conserving water have been built, so that additional areas can be brought under irrigation by completing other units.

The building of large structures for water conservation and for the reclamation of land is not, however, the ultimate object. These works in themselves are notable, but their importance to the nation comes from the fact that they make possible opportunities for the creation of small farms and building of homes for an independent citizenship. The question of prime interest to the general public is not so much that of how far these works may be extended, but what may be accomplished through them by the reclamation of lands otherwise valueless.

Throughout an extent of land, equalling fully two-fifths of the area of the entire United States, there is not enough rain, at least 
in the crop season, for the needs of useful plants, and for success in agriculture there must be a constant supply of water, artificially controlled and brought to the fields. Between the two extremeson the east a humid region with occasional summer droughts, and on the west a truly arid region where all plants need irrigationlies a broad and somewhat debatable belt of land known as subhumid or semi-arid region, within which irrigation is valuable, but where the need is not so pressing as to render the practice always successful. In the arid region there is no question as to what may be accomplished by reclamation. The extent of the accomplishments are bounded simply by available water supply, and the acreage which will be reclaimed in the future can be given accurately when facts become available as to the quantity of water which may be stored or pumped to the dry lands.

In the semi-arid region, however, the question is a little more complicated, as the extent to which irrigation may be extended in the future is modified by the possibilities of finding useful droughtresisting plants which can be cultivated on the rich soil where the water supply is now somewhat deficient. Our present knowledge of the water supply available for use in both the arid and semi-arid regions is not sufficient to state accurately the limits which are set by nature to the irrigable areas.

There is more good land in the arid region than there is water for it. If all the run-off waters of this region could be conserved and employed in irrigation, the total reclaimed area might, perhaps, be brought to nearly $60,000,000$ acres. This is uncertain, however, as our data on run-off are confined to a portion only of the streams, and are incomplete even for these; furthermore, such an estimate involves assumptions regarding the duty of water that may introduce large errors; that is to say, we do not know in all cases how much land can be irrigated by a given amount of water. It is known, moreover, that large portions of the water of the arid region can not be used in irrigation, as no irrigable land exists upon which it can be brought at feasible cost.

In general it may be stated that the value of irrigated land is increasing while improvements in machinery are tending to decrease costs of construction of reclamation works, so that it is impossible to draw an exact line between the probable and improbable schemes, even if we had full knowledge regarding present costs. This would 
require elaborate surveys, which have not been made. For these reasons any present estimate of the total irrigable area is necessarily little better than a guess. With present data, the closest statement is probably under 60,000,000 acres and between 40,000,000 and 50,000,000 acres, including the lands now under ditch.

The subjects of irrigation, forestry, power, domestic water supply, drainage and navigation are all closely interrelated and should be thoroughly studied together, not only in the arid, but in the humid regions. No one of these questions can be properly treated without full regard to all the others. Proper study of these comprehensive subjects should include more extended observations of rainfall and evaporation, especially in high altitudes, and of the annual flow of all streams. Topographic maps should be made showing the areas of drainage basin, the location of reservoir sites, and their relation in altitude and location to irrigable lands and to power and navigation resources. Such maps are the basic information most urgently needed for all land classification, and without them no wise policy can be adopted.

Both state and national laws are incomplete in permitting and encouraging settlement on lands which should be reserved for reservoir sites. Thorough surveys should be made and all feasible reservoir sites, when discovered, should be reserved for development.

The present laws in some states tend to promote irrigation, but in others they do not. The most primitive form of the regulation of water in irrigation is best exemplified by the present laws of the State of California. These declare the principles of priority and beneficial use, and provide that claims to the use of water shall be recorded in the form of a notice of appropriation, and shall be perfected by application to a beneficial use. At the same time they try. to recognize as concurrent on the same stream, rights derived by prior appropriation and rights depending on riparian ownership. The riparian doctrine of water rights should be definitely and permanently abrogated in all arid regions. This has been done in some states by constitutional provision and in some by judicial decision. In all the states of the arid region where the riparian doctrine is recognized material modifications in the old common-law doctrine have been made and put into effect.

The progress of reclamation in many of the western states will 
be extremely slow until better laws are passed covering some of the important points above indicated. The uncertainties concerning rights to water are so great that no one would be justified in incurring large expenditures without better safeguards. The conditions are very much as though we had no system for describing or recording land titles, and every man could claim all of the land he desired, leaving it to the courts from time to time to determine how much land was actually used by each man. The litigation which results from this indefinite condition is endless, since it frequently determines only the relative rights of two men and leaves out of account the rights of third parties or of the public. The confusion which now exists with reference to water titles is indescribable, excepting in those states where a definite system of measuring and recording the amount of water has been adopted.

With larger knowledge of the subject, with better laws, and with skill in handling water, it will be possible to reclaim the vast areas above mentioned, and to make opportunities for at least a million farms and homes, supporting directly five millions of people, and indirectly enabling an equal or greater number of people to be supported through the transportation and manufacturing business which grows up incidental to farming. The yield per acre of the reclaimed land is so great that when completely utilized it is possible that it will support, directly or indirectly, a population averaging very nearly one to the acre. This means communities nearly independent of the effect of fluctuating trade conditions, or of wet or dry weather, and a people more nearly self-supporting than any other similar number in the country. It means a citizenship attached to the soil and with the incentives to the highest patriotism. 